\title{
Clinical implications of intratumor heterogeneity: challenges and opportunities
}

\author{
Santiago Ramón y Cajal ${ }^{1,2,3,4}$ - Marta Sesé ${ }^{1,3} \cdot$ Claudia Capdevila $^{1,5} \cdot$ Trond Aasen $^{1,3} \cdot$ Leticia De Mattos-Arruda $^{6}$. \\ Salvador J. Diaz-Cano ${ }^{7}$. Javier Hernández-Losa ${ }^{1,2,3}$ • Josep Castellví ${ }^{1,2,3}$
}

Received: 10 May 2019 / Revised: 5 November 2019 / Accepted: 7 January 2020 / Published online: 22 January 2020

(C) The Author(s) 2020

\begin{abstract}
In this review, we highlight the role of intratumoral heterogeneity, focusing on the clinical and biological ramifications this phenomenon poses. Intratumoral heterogeneity arises through complex genetic, epigenetic, and protein modifications that drive phenotypic selection in response to environmental pressures. Functionally, heterogeneity provides tumors with significant adaptability. This ranges from mutual beneficial cooperation between cells, which nurture features such as growth and metastasis, to the narrow escape and survival of clonal cell populations that have adapted to thrive under specific conditions such as hypoxia or chemotherapy. These dynamic intercellular interplays are guided by a Darwinian selection landscape between clonal tumor cell populations and the tumor microenvironment. Understanding the involved drivers and functional consequences of such tumor heterogeneity is challenging but also promises to provide novel insight needed to confront the problem of therapeutic resistance in tumors.
\end{abstract}

Keywords Intratumor heterogeneity $\cdot$ Liquid biopsy $\cdot$ Artificial intelligence $\cdot$ Antitumor therapeutics

\section{Background}

Malignant tumors have highly diverse phenotypic and molecular characteristics both at the intertumor and intratumor levels [1]. Intertumor heterogeneity (also known as interlesion heterogeneity) refers to the differences found between tumors in different patients. Intratumor heterogeneity (also known as intralesion heterogeneity) refers to distinct tumor cell populations (with different molecular and phenotypical profiles) within the same tumor specimen [1].
Santiago Ramón y Cajal

sramon@vhebron.net

Marta Sesé

marta.sese@vhir.org

Claudia Capdevila cc4107@cumc.columbia.edu

Trond Aasen

trond.aasen@vhir.org

Leticia De Mattos-Arruda

ldemattos@vhio.net

Salvador J. Diaz-Cano

sdiaz-cano@nhs.net

Javier Hernández-Losa jahernan@vhebron.net

Josep Castellví

jocastellvi@vhebron.net
1 Translational Molecular Pathology, Vall d'Hebron Institute of Research (VHIR), Universitat Autònoma de Barcelona, Passeig Vall d'Hebron 119-129, 08035 Barcelona, Spain

2 Pathology Department, Vall d'Hebron Hospital, Passeig Vall d'Hebron 119-129, 08035 Barcelona, Spain

3 Spanish Biomedical Research Network Centre in Oncology (CIBERONC), Barcelona, Spain

4 Department of Pathology, Vall d'Hebron University Hospital, Autonomous University of Barcelona, Pg. Vall d'Hebron, 119-129, 08035 Barcelona, Spain

5 Department of Genetics and Development, Columbia University Medical Center, New York, NY 10032, USA

6 Vall d'Hebron Institute of Oncology, Vall d'Hebron University Hospital, c/Natzaret, 115-117, 08035 Barcelona, Spain

7 Department of Histopathology, King's College Hospital and King's Health Partners, London, UK 
Cancer is typically defined as a genetic disease driven by oncogenic mutations. In a similar gene-centric view, intratumoral heterogeneity has traditionally been attributed to genetic diversity within cancer cell populations. However, recent evidence suggests that a tumor is heterogeneous in almost every discernible phenotypic trait as the result of not only genetic influences but also nongenetic sources of variability [2]. These non-genetic influences shape the phenotypic states of cancer cells at the proteome level. These factors are the primary determinants of the identity of most cell types in healthy tissue, given that most cells, while phenotypically different, share the same genetic load.

Tumor heterogeneity is associated with poor prognosis and outcome [3-6]. It is thought that intratumor heterogeneity is one of the leading determinants of therapeutic resistance and treatment failure and one of the main reasons for poor overall survival in cancer patients with metastatic disease [1,7]. Tumors are composed of mosaics of cancer cells with different characteristics and varying sensitivities to anticancer therapies. Tumor heterogeneity has differential layers of complexity. Because cancer is a heterogeneous dynamic target, individual patients, lesions, and cell populations should be thoroughly characterized at varying times. Tumor heterogeneity has presented a considerable challenge to matching patients with the right treatment at the right time; therefore, it poses a challenge to accomplish the goals of precision medicine $[8,9]$.

It has been shown that most of the targets considered as druggable and for which Food and Drug Administration (FDA)-approved therapeutics are available are not expressed in a uniform or homogeneous manner in tumor tissue. Examples include the variable threshold of positivity for the expression of the HER2 receptor in gastric adenocarcinoma [10], progesterone and estrogen receptors in breast tumors [11], the EML4-ALK translocation in lung adenocarcinoma [12], B-RAF mutations in melanoma, and the $1 \mathrm{p} / 19 \mathrm{q}$ allelic loss in oligodendrogliomas [13, 14]. This variability means that many patients undergo specific therapeutic regimens in situations where perhaps only $10 \%$ of the studied tumor cells are positive for the corresponding target. Thus, targeted therapies in heterogeneous neoplasms lead to transient tumor regression and subsequent selective outgrowth of existing resistant populations, leading to recurrence in the long run.

In the following sections, we discuss intratumor heterogeneity and in particular how this is driven at the genetic level and in relation to the microenvironment, and how this translates into specific phenotypes at the functional level. Finally, we discuss research approaches needed to advance our understanding of this complex biological phenomenon and how this can lead to novel therapeutic approaches.
Phenotypic heterogeneity: the particular case
of morphologic heterogeneity

Every tumor is unique as a result of its interactions with the host and the genetic and epigenetic variability. This results in important differences between tumors from different individuals, named as intertumoral heterogeneity. At this level, we recognize more than 250 types of tumors with distinctive clinicalpathological characteristics and that show most of them also peculiar pathological characteristics. In most of these tumor types, dozens or hundreds of pathological variants are observed. In such variability of tumors and, therefore, of types of cancer, factors such as the location and the cell type are determinant.

Neoplastic lesions are diagnosed primarily based on pathological examination, both gross and microscopic, but the information obtained may not always be conclusive for a diagnosis of malignancy. In this context, intratumoral heterogeneity poses an unresolved problem. Most carcinomas, sarcomas, and astrocytomas display extensive intratumoral morphological variability that, if not taken into account, can lead to an inaccurate or even incorrect diagnosis. For example, analysis of complete specimens of lung adenocarcinoma often reveals more than one morphological pattern (acinar, solid, lipid, papillary, micropapillary, mucinous, or pleomorphic) (Fig. 1) [15], and accurate assessment is critical for the right diagnosis and prognosis. Therefore, diagnosis based on morphology requires extensive areas of the tumor to be examined to ensure an objective, genuinely representative snapshot of the heterogeneity within the tumor as a whole. State-of-the-art digital image acquisition and quantification algorithms, which integrate biophysical parameters to capture the spatial variation in tumor architectures, are likely to play an essential role in this [16].

In many malignant tumors, it is common to find welldifferentiated areas adjacent to poorly or moderately differentiated areas. Attempts are currently being made to quantify these areas and grade tumors, generally according to the least-differentiated area or the area with the highest degree of cytologic malignancy [17, 18]. This intratumoral differentiation is often patchy, and not well defined in molecular terms. It reproduces the development patterns and morphofunctional specialization present in the tissue where cancer originated and can lead to differences in the expression of some of the therapeutic targets and, therefore, the response to a specific treatment $[10,19-21]$. One of the most characteristic examples is EGFR-driven lung adenocarcinoma in non small-cell lung cancer (NSCLC), as there have been cases of resistance associated with conversion to small-cell lung cancer (SCLC) phenotype after long-term treatment with EGFR tyrosine kinase inhibitors [22].

Similarly, the observation of specific morphologic patterns in human tumors has made it possible to identify distinct genetic changes. For example, characteristic chromosomal translocations have been identified in round cell desmoplastic 


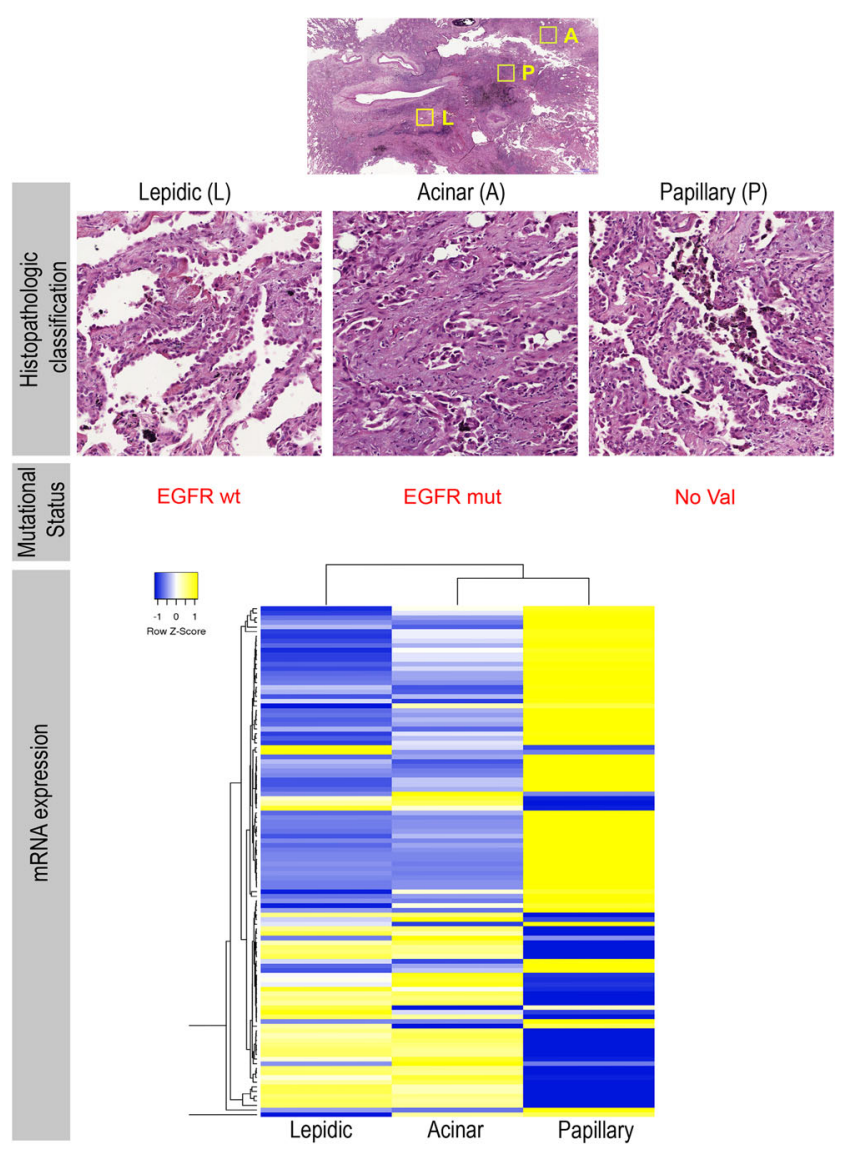

Fig. 1 Lung cancer intratumoral heterogeneity at morphological and molecular levels. a Paraffin section of a lung tumor biopsy showing three main morphological subtypes within the same tumor. b Molecular and biomarker analysis confirming heterogeneity in EGFR mutation and in the $\mathbf{c}$ transcriptional signature of these three subtypes

tumors, clear cell sarcoma, synovial sarcoma, and rhabdoid tumors [23, 24]. Nevertheless, not all oncogenic changes are diagnostic determinants of a specific tumor type or give rise to the emergence of a specific morphologic pattern. Researchers from the National Research Tomsk State University [25] have shown that the morphological heterogeneity in invasive micropapillary carcinoma (IMPC) of the breast is not related to the presence of specific chromosomal aberrations. This heterogeneity responds to specific gene expression profiles, thus pointing to the existence of other determinants of intratumor morphological heterogeneity and highlighting the importance of context. Furthermore, some of the most common molecular alterations have been associated with tumors whose morphological characteristics are strikingly distinct.

\section{Molecular heterogeneity: a genomic substrate for both tumor biology and evolution}

During the 1990s, and after the discovery of oncogenes, it was thought that specific genetic changes would account for tumor heterogeneity and the emergence of an eventual phenotype of resistance to many conventional treatments.

Nevertheless, the puzzle and variability of cancer pathology are made tremendously complicated at the genomic level by the vast number of DNA changes, with thousands of known translocations and more than 1500 mutations, deletions, and amplifications reported to date [8, 26-29]. Also noteworthy is the complex world of microRNAs (miRNAs), of which there are thousands described (www.mirbase.org) and which can act like oncogenes or tumor suppressors (oncomiRs and tumor suppressor miRs) [30,31], and the unknown role of long non-coding RNA (lncRNA), numbering as many as 60,000 loci in the human genome [32-34]. Importantly, there are many nonspecific genetic alterations in human tumors. For example, the ETV6-NTRK3 translocation can be detected in very different types of tumors such as infantile fibrosarcoma, cellular mesoblastic nephroma, and secretory carcinoma of the breast [35]. Chromosomal translocations such as those including the ALK gene are demonstrated in anaplastic lymphoma, lung adenocarcinoma, and myofibroblastic tumors [36], and the translocation EWSR1-CREB1 in tumors as different as clear cell sarcoma and angiomatoid fibrous histiocytoma [37]. BRAF mutations and translocations have been described in melanocytic nevi, malignant melanoma, colon adenocarcinoma, glioblastoma and pilocytic astrocytoma $[38,39]$ and EGFR mutations, amplifications in lung adenocarcinoma and brain tumors [40-42].

Although some molecular alterations are recurrent in some tumors, not all the tumors of the same type, and similar morphology, show the same genetic profile. In fact, there is a huge intertumoral heterogeneity between tumors with the same histology in different individuals. This heterogeneity poses a problem when trying to standardize a therapy in a specific tumor type, requiring a personalized approach based on the particular genetic alterations of the tumor, to improve the response rates to the treatment.

Moreover, initial studies have shown that a characteristic morphological pattern could be due to specific oncogenic changes and that malignancy is dependent on the immune response [43]. For example, primary cells with RAS, NEU, mutated p53, MYC, and the viral gene E1A oncogenes injected into athymic mice [43] form different morphological patterns in melanoma [17]. In this sense, the first point to underline would be that the presence of different morphological patterns within the same tumor suggests the coexistence of various clones, each subject to specific genetic changes or different environmental pressures that are not necessarily shared by clones present in other areas.

Critically, this genetic variability is also thought to occur extensively within a tumor (Fig. 1). Therefore, the goal of 
preparing selective oncograms with chemotherapy drugs and other inhibitors has become complicated-almost impossible-following conventional strategies. Intratumor molecular heterogeneity, and more specifically that occurring intratumorally, is thought to account for the unsuccessful attempts of pharmacologic and radiologic cancer treatments. In fact, in cell lines, a correlation has previously been shown between resistance to radiotherapy and cytotoxic drugs (e.g., cisplatin, doxorubicin, and taxanes) and the expression of specific oncogenes, principally, RAS, p53, c-MYC, and the adenoviral gene E1A [44-47].

\section{Causes of molecular heterogeneity}

There are a lot of redundant genetic alterations in cellular and biological pathways. These pathways can be grouped into specific "hallmarks" or basic principles that rationalize tumor biology and that are altered in the vast majority of malignant neoplasms [48, 49]. Authors have postulated that the most important aspect of tumor transformation and subsequent progression is the functional alteration of at least ten major biochemical pathways. Given that phenotypes generated by changes in genetic material are the substrate of clonal development and selection and adaptation to the microenvironment for each of these pathways (e.g., insensitivity to apoptosis, self-sufficiency in cell proliferation, acquisition of so-called replicative immortality), several significant genetic changes must occur (Fig. 2) [62]. A representative example can be seen in signaling in the Ras/MAPK and PTEN/PI3K/AKT axes in lung adenocarcinomas, where specific mutations, amplifications, gene expression, and translocations in membrane receptors, as in other genes downstream, can enable the tumor cell hallmark of uncontrolled proliferation $[60$, 63].

This concept can be extrapolated to other significant pathways, whose number is expected to grow to $15-20$ in the coming years [49]. Although "single hit pathways" are
Fig. 2 Clonal cooperation and cellular consortium. a Darwinian model of clonal heterogeneity resulting in a consortium of clones, each with their characteristics and malignant features. b Cooperation between several clones to invade and metastasize

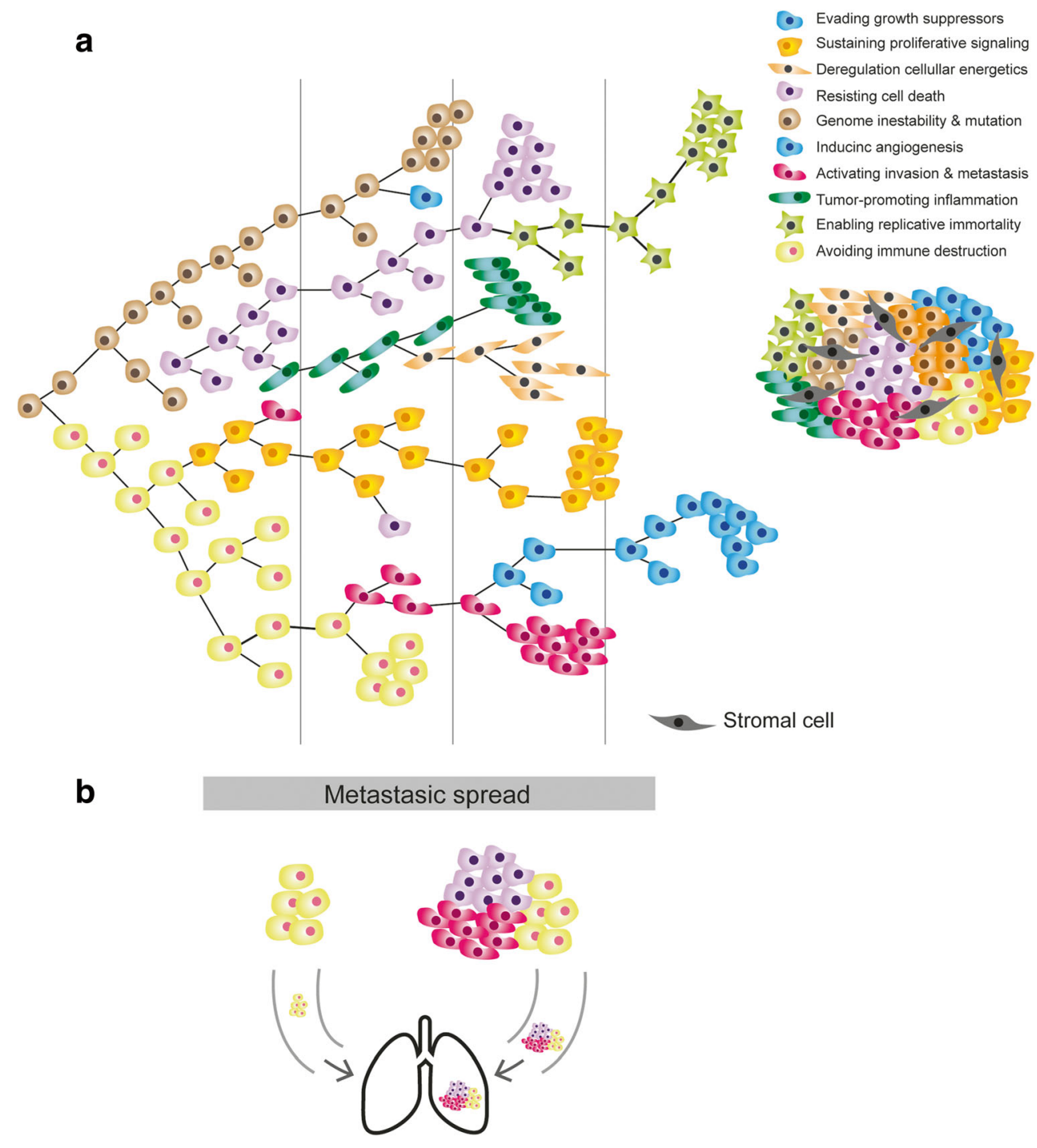


reported, disruptions of several pathways are necessary for a cell to become malignant. Moreover, a similar biological effect can be achieved by hitting a particular biochemical pathway at different points, often driven by the inherent genetic instability of a tumor, thus making cancer an extremely heterogeneous (and redundant) disease at the molecular level [54, 64, 65] (Fig. 1).

\section{Understanding the role of genomic instability as an enabling characteristic of cancer}

Despite claims in recent models that only three driver mutations are required for the development of various forms of advanced cancer $[66,67]$, the number of molecular changes necessary to enable the emergence of a clinically relevant tumor has, for some time, been assumed to be higher than previously thought, given standard mutation rates in any cell type. This observation is supported by the large number of somatic mutations and epigenetic alterations found in most tumor specimens (in the order of thousands), which points to the existence of molecular mechanisms that enable the mutational landscape of cancer cells to expand. Therefore, to explain the substantial molecular variability inherent to malignant tumors, there must be a background of replicative immortality and genomic instability, which is associated with abnormalities in DNA repair mechanisms and maintenance of genetic and chromosomal integrity (see review [68]). Chromosome instability (CIN) and microsatellite instability (MSI) have been described as two alternative pathways to cancer $[53,69,70]$.

\section{Epigenetic heterogeneity}

Genetically identical cell populations can display remarkable morphological diversity. One mechanism by which different environmental stimuli drive such heterogeneity is by epigenetic modifications of the genome, which can persist over many cell divisions [61]. Therefore, within what we understand as molecular heterogeneity, regional differences in epigenetic status have been observed in different types of cancer that can act, in much the same way as genetic alterations, as drivers of the tumor process. For example, in colon adenocarcinomas, a subtype harbors a relevant profile of epigenetic alterations [64]; this is also seen in urological [65] and other tumors [57, 58, 71]. Moreover, local hypoxia may induce the expression of histone demethylases and other epigenetic modifiers that subsequently modulate the expression of genes linked to a specific phenotype (e.g., leading to epithelial to mesenchymal transition). Inflammatory cytokines are another example, released by stromal or immune cells, which can alter DNA methylation and other epigenetic markers.
Many of these regional epigenetic differences are associated with an aberrant methylation pattern in specific promoters or other regulatory elements causing either gene activation or silencing [59, 72-77], which may also be predictive of the phylogenetic relationships between the different clones in tumors such as prostate cancer [78]. Therefore, we can deduce that genomic and epigenomic diversity are not mutually exclusive but can be explained by a unified evolutionary process, giving rise to more robust evolutionary models than clonal relationships inferred from genetic or epigenetic datasets alone. A summary of main molecular events related with intratumoral heterogeneity is shown in Table 1.

\section{Proteomic heterogeneity: going beyond the genome}

If the genetic diversity of constitutive alterations in DNA is enormous, then at the level of the proteome, this diversity increases exponentially. Given that proteins are the final effectors of all cellular pathways, along with small metabolites, it seems reasonable to think that the "ideal" targets for therapy are those protein factors that have the most stable expression and activation in tumor cells. Therefore, it is essential to consider the proteomic heterogeneity of tumors.

Even in tumors with constitutive genetic activation of EGFR and HER2, the underlying pathways are not permanently and homogeneously active in all cells [79-83]. At present, approaches such as multispectral imaging of multiple proteins from a common signaling pathway allow the accessible, multiplexed elucidation of proteomic heterogeneity at the level of signal transduction [84]. Moreover, proteomic heterogeneity is not always a simple consequence of the heterogeneity found at the genetic level. In fact, it may be affected by the microenvironment and stress situations such as starving or hypoxia [62, 85].

Much attention has been paid to the role of the molecular pathways controlling RNA splicing [86, 87], the impact of the expression of various protein isoforms, and how the local environmental factors determine their levels [88]. However, protein synthesis machinery and other translation regulators are also significantly modulated by local environmental conditions. Control of protein synthesis (and preceded immediately by regulation of transcription) is considered one of the leading post-transcriptional mechanisms for control of gene expression. This control is profoundly altered in cancer [56].

Alterations in the expression and activity of specific translation factors and their inhibition by cellular stress conditions (e.g. hypoxia or lack of nutrients through various pathways) are common to most human tumors (especially in advanced stages) [56]. The tumor takes control of translation by various mechanisms to cover the demands associated with high proliferation rates or to promote translation of specific messengers that are favorable to tumor progression (survival, proangiogenic, invasion, and metastasis) (reviewed in [89]). 
Table 1 Table summarizing the aspects highlighted in this review correlating with the key molecular events related with intratumoral heterogeneity

\begin{tabular}{|c|c|c|}
\hline & Key points & Bibliography \\
\hline \multirow[t]{4}{*}{ 1. Phenotypic heterogeneity } & 1.1. Hundreds of tumor types and thousands of subtypes & Jamal-Hanjani et al. (2015) [1] \\
\hline & $\begin{array}{l}\text { 1.2. Different degree of cell differentiation (low-grade and } \\
\text { high-grade tumor types) }\end{array}$ & Park et al. (2010) [18] Zhou et al. (2015) [17] \\
\hline & 1.3. Morphologic pattern association with genetic changes & $\begin{array}{l}\text { Sequist et al. (2011) [22] Nielsen et al. (2015) [24] Zack } \\
\text { et al. (2013) [26] }\end{array}$ \\
\hline & $\begin{array}{l}\text { 1.4. Morphological heterogeneity in metastasis vs. primary } \\
\text { tumor }\end{array}$ & Maddipati et al. (2015) [50] Hong et al. (2015) [51] \\
\hline \multirow[t]{8}{*}{ 2. Molecular heterogeneity } & 2.1. Intratumor heterogeneity and resistance to treatments & Dagogo-Jack and Shaw (2018) [52] \\
\hline & $\begin{array}{l}\text { 2.2. Different types of molecular changes in coding genes } \\
\text { 2.2.1 SNV }\end{array}$ & $\begin{array}{l}\text { JamalHanjani et al. (2017) [7] Sharma and Debinski } \\
\text { (2018) [41] Karachaliou et al. (2015) [40] }\end{array}$ \\
\hline & 2.2.2 Insertions and Deletions & \\
\hline & 2.2.3 Copy number variation & \\
\hline & 2.2.4 Rearrangements (i.e translocations) & Skoulidis and Heymach (2019) [42] \\
\hline & 2.3. Genomic Instability (CIN and MSI) & $\begin{array}{l}\text { Dagogo-Jack and Shaw (2018) [52] Andor et al. (2016) } \\
\text { [53] }\end{array}$ \\
\hline & $\begin{array}{l}\text { 2.4. Molecular and biochemical redundancy in the several } \\
\text { pathways altered in malignant cells }\end{array}$ & Logue and Morrison (2012) [54] \\
\hline & $\begin{array}{l}\text { 2.5. Heterogeneity at genomic level is not always related with } \\
\text { heterogeneity at proteomic level }\end{array}$ & $\begin{array}{l}\text { Ramon Y Cajal S et al. (2017) [55] Ramon Y Cajal S } \\
\text { et al. (2018) [56] }\end{array}$ \\
\hline \multirow[t]{4}{*}{ 3. Epigenetic heterogeneity } & $\begin{array}{l}\text { 3.1 Different changes (histone modifications, DNA } \\
\text { methylation) on the genome associated with gene } \\
\text { silencing / gene activation }\end{array}$ & $\begin{array}{l}\text { Kumar et al. (2018) [57] Dong et al. (2017) [58] Bhawal } \\
\text { et al. (2007) [59] }\end{array}$ \\
\hline & $\begin{array}{l}\text { 3.2. Deregulation of gene expression (overexpression or } \\
\text { inhibition) } \\
\text { 3.2.1 conding genes: mRNAs }\end{array}$ & Agarwal R et al. (2017) [60] \\
\hline & 3.2.2 non-coding RNAs: miRNAs, lncRNAs & $\begin{array}{l}\text { Raychaudhuri et al. (2012) [33] Eriksen et al. (2016) } \\
\text { [31] Ramon y Cajal et al.(2019) [34] }\end{array}$ \\
\hline & 3.3. Associated and associated with the microenvironment & Assenov et al. (2018) [61] Yuan Y (2016) [62] \\
\hline
\end{tabular}

\section{Biological interactions among distinct tumor clones and the microenvironment: the stroma may have a significant impact on phenotypic heterogeneity}

Twenty years ago, we published the first histopathologic evaluation of whether differentiation in squamous cell carcinoma could be related to the components of the stroma [90]. After previous studies by Dotto and Weinberg [91], who observed that normal fibroblasts could inhibit the growth of RAS-transformed keratinocytes in athymic mice, we observed that coinjection of normal fibroblasts together with RAS-transformed keratinocytes induced benign or low-grade malignant squamous lesions with extensive areas of keratinization that were observable by morphology, by immunohistochemistry, and by electron microscopy [90]. Subsequently, it was concluded that this fibroblast-mediated differentiation was secondary to factors such as signaling by transforming growth factor beta (TGF- $\beta$ ).

Years of research have shown that the peritumoral stroma in many malignant tumors play an important role and can secrete factors associated with poor prognosis (e.g., chemokines secreted by tumor-associated histiocytes, macrophages or fibroblasts [the so-called cancer-associated fibroblasts]). Signatures of released stromal factors have been thought to affect progression and tumor differentiation, as well as invasiveness in adenocarcinomas [92-95]. Therefore, the importance of the surrounding stroma in intratumoral morphologic heterogeneity seems evident, both regarding factors released by fibroblasts and factors released by inflammatory cells such as histiocytes and lymphocytes. Accordingly, tumor multifocality has been postulated as being associated with the underlying stroma [96]. Morphological and genetic heterogeneity is the result of a multistep process of tumorigenesis that leads to subclonal tumor cell populations with distinct traits, according to current paradigms $[2,5,8,21]$. The model we present herein incorporates complementary theories of tumor evolution such as the big bang model or the cancer stem cell hypothesis [97] (Fig. 2). It is increasingly clear that understanding alterations within tumor cells is only part of the picture, and we need to understand interactions between tumors and their microenvironment to 
account for multiple aspects of tumor progression and therapeutic resilience [55, 98-100].

In this regard, the concept of cancer as a consortium of clones and local factors has been proposed [101]. The concept of clonal cooperation is based on a single clone being unable to acquire all the necessary properties to be an invasive tumor, such that various clones must act synergistically and complementarily to acquire the characteristics described by Hanahan and Weinberg [49] and the proposed biochemical changes in 10 or more cellular biochemical pathways. This cell cooperation can be observed in cell clusters in metastatic development: clusters of circulating tumor cells (CTCs) are associated with higher number of metastases than single circulating cells in models of breast cancer, pancreatic cancer, and melanoma [50, 51, 102-106]. Moreover, our group made an effort to generate MDA-MB-231 breast cancer cell lines single clones and demonstrated that the clonal cooperation confers aggressiveness and tumor progression [106].

The microenvironment plays a role in the adoption of phenotypes that may be clinically relevant and are contingent upon the implementation of metabolic gene expression programs and, as such, can be completely independent of the acquisition of new drivers. One of the most explicit examples is the well-known role of the HIF family of transcription factors, which, under hypoxic conditions, trigger a set of adaptive transcriptional responses (tumor angiogenesis, cell metabolism, invasion, survival, therapeutic resistance, and even differentiation and self-renewal) and seem to play a critical role in tumor progression [107].

\section{How to address tumor heterogeneity in a clinical setting}

Intratumor heterogeneity (and its genetic and non-genetic determinants) is a dynamic phenomenon that is observed at multiple levels, and that follows a mainly Darwinian-type progression, although it is far more complicated than previously thought. Unpredictable and often chaotic cellular reactions depending on oncogenic alterations and environmental factors drive tumor progression and hold the key to interpreting tumor development. This concept is essential because the decisions made during a patient's treatment are based on the study of biopsy specimens of the primary tumor by pathologists and usually revolve around the oncogenic drivers known at the time of diagnosis [2] (Fig. 3). Given the complex and constant development of tumor architecture, it is essential to understand that molecular changes (both genetic and epigenetic) within the tumor itself evolve during disease progression and metastasis [108]. Therefore, the biopsy of a primary tumor is not necessarily predictive of what happens in secondary deposits [2]. In addition, chemotherapy and radiotherapy can trigger selection of resistant clones $[2,109,110]$, induce new mutations and other genetic and chromosomal rearrangements $[21,111]$, recover functionality of previously inactivated genes whose potential had been exploited in synthetic lethal interactions [112], activate cellular dedifferentiation and transdifferentiation programs [97], and even potentiate the development of specific populations by non-cell-autonomous mechanisms [113]. Thus, it is the adoption of both genetic and non-genetic subclonal changes that endows cancer with enough phenotypical plasticity to adapt to microenvironmental pressures and successfully overcome the barriers posed by antitumoral therapy. Otherwise, dissecting tumor heterogeneity involves emerging strategies such as multiregional sequencing, analysis of autopsy samples, single-cell sequencing, and longitudinal analysis of liquid biopsy samples [52]. Rapid research autopsy of cancer patients can explain heterogeneity processes including cancer evolution and acquired therapeutic resistance [114-119].

Numerous studies have shown how genetic variants emerge after therapy and suggest that resistance and response to therapy from that moment onwards are commonly determined by genetic variants (see [8] and references therein). For example, in colon adenocarcinoma, highly sensitive techniques and application of anti-EGFR therapy have made it possible to detect up to $70 \%$ of Ras mutations in blood in series where the percentage diagnosed in the primary tumor was approximately $40-45 \%$ based on standard molecular techniques [120]. This is also true for non-small cell lung cancer and EGFR mutations [40]. In this sense, therapy has been considered both a source of variability and a selective filter, promoting the acquisition of new mutations and the selective proliferation of previously dormant, minority clones $[21,121]$.

Given that the strategy of targeting cancer-initiating mutations has been applied with limited success [122], we believe that better comprehension of the determinants of tumor heterogeneity is needed (especially in intratumor terms). Pathologists have the responsibility to make a correct and verifiable diagnosis, from their examination of tissue samples, taking into consideration all the variables that underlie intratumoral heterogeneity. Tumor progression assessment would ideally analyze at least two samples to compare the biologic markers relevant for progression in both tumor cell clones and the microenvironment. The tumor clone markers include those involved in the tumorigenic expansion (proliferation) and invasion, the two leading forces driving progression. The tumor microenvironment analysis focuses the attention on the qualities that potentiate clonal expansion and invasion of tumor cells. In essence, tumor progression analysis must concentrate on clonal heterogeneity and overcome the problems it presents.

One important aspect is how representative biopsies reflects the overall tumor histology and biology. Core biopsies often only reflect a spatiotemporal snapshot of the whole 


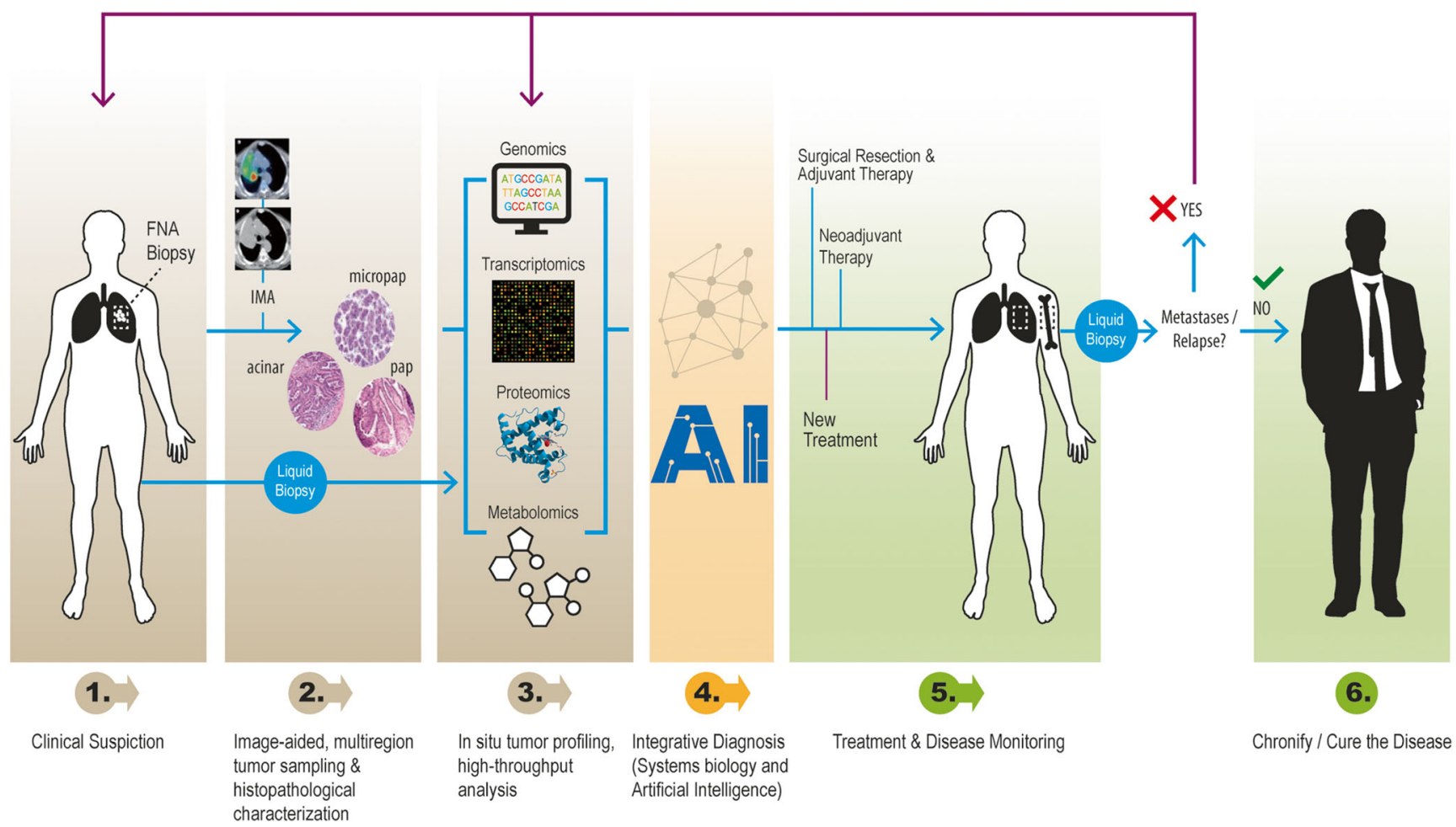

Fig. 3 Cancer biology-driven personalized medicine. Schematic representation of the clinical workflow for lung cancer diagnosis, treatment, and followup

tumor and are therefore unlikely to be fully informative about the clonal composition [123-129]. The size of the sample is another critical issue [130-132], and signal-to-noise ratios need to be balanced. One way to achieve this balance is isolate by microdissection multiple relatively small regions of tumors that more likely represent the balance of morphologically distinct units. The importance of such approach is highlighted by the observation of clustered populations within a tumor that differ in gene expression [133], as well as genetic composition [134]. However, unless large numbers of samples are provided for each tumor, this approach can easily fail to identify patches of genetically distinct cells [130-132]. On the other hand, larger samples, or pools of samples, lead to intermixing of small anatomically distinct units, which provides additional challenges in relation to distinguish distinct functional heterogeneity. Multiple solid biopsy samples should be taken based on data obtained through imaging and nuclear medicine, with the selection of the biopsied area relying increasingly on criteria such as particular metabolic activity. It is also essential to bear in mind that microenvironmental factors such as hypoxia and inflammatory infiltrate can induce changes in the protein expression of therapeutic targets and condition the response to antitumor agents. Therefore, we must select the most representative areas for massive parallel sequencing and genomic and proteomic studies and report on their limitations.

The histopathological diagnosis should integrate molecular analysis (genome sequencing, transcriptome profiling) and protein expression profiling (especially analyses including next-generation sequencing (NGS) techniques) and be able to include gene signatures that are characteristic of a different prognosis or clinical treatment [55, 70, 92, 94, 130, 135-137] (Fig. 3). The incorporation of NGS and the development of new resources for the analysis of these big data, combining molecular and expression signatures, are becoming crucial for diagnosis $[13,138]$. The field of radiogenomics, which correlates genomic data with the radiological features of the tumors, must also be taken into account $[139,140]$. While this approach based on artificial intelligence may be interesting for the differential diagnosis of radiological features, we understand that genomic information from a single sample is not necessarily representative of the whole tumor and its heterogeneity. While procuring multiple metastatic tumor samples for genomic studies through NGS and development of patientderived xenografts or organoids, mechanistic insights gained from research autopsy studies of cancer patients can help identify new targets for therapeutic intervention [114]. In collaboration with Cambridge CRUK, our group has performed extensive multi-platform profiling of metastases in 10 warm autopsies of patients with lethal multi-therapy-resistant breast cancers (DNA sequencing, RNA sequencing, the T cell receptor (TCR) sequencing, and immunohistochemistry (IHC)) of multiple individual metastases (range 5-36 metastases per case, 182 individual metastases to 22 organ sites). This collection allowed us to characterize the mutational and copy 
number aberration (CNA) landscapes across the individual metastasis, to infer the clonal ancestries of metastases, to assess the TME in each individual metastasis, to characterize the predicted neo-antigens, and to assess the TCR repertoires across metastases, providing an unprecedented molecular characterization of lethal breast cancers that had been subjected to multiple lines of systemic therapies [119].

Finally, one of the most powerful techniques is the study of tumor heterogeneity at the cellular level. This approach, called single-cell sequencing, is based on the isolation of dozens of cells in different areas of the tumor, and the study of various Multi(omics) over them [141, 142]. For example, DNA sequencing after gene amplification can allow the study of mutations, amplifications, deletions, and translocations in various areas of the tumor, thus characterizing the homogeneity of these genetic alterations [141, 143, 144]. Expression studies are also done, both at the RNA level (RNA-Seq) and epigenetics with methyloma sequencing [143, 145, 146]. These studies, nowadays, can be expensive and tedious in time as well as in their interpretation, but are already showing results of high clinical interest; for example, the identification of heterogeneity of mutations of the PIK3CA gene in breast cancer with HER2 amplification where the authors describe that PIK13A and HER2 are not always present in the same cells and that chemotherapy selected the cells with mutant PIK3CA [111]. It is an example of the importance of studying intratumoral molecular heterogeneity and where single-cell sequencing technology can be decisive.

\section{How do we envision cancer research and treatment in the coming years?}

(1) To assess intratumoral heterogeneity of tumors efficiently, it is essential to systematically integrate molecular patterns, protein expression, and morphology into the fuller context of all clinical and pathological information available (Fig. 3). We have proposed the term tissunomics, whereby a diagnosis is individually assessed based upon a combined picture derived from the clinical, pathological, molecular, and protein expression data of the tumor and its surrounding microenvironment [55]. Importantly, molecular diagnosis based on small samples and genetic alterations can lead to a false negative diagnosis or treatment due to genetic and epigenetic changes present in a small subset of tumor cells. In addition, tumor type and location has been shown to underlie unpredictable treatment responses targeting the same molecular pathway, such as the tumor response in melanomas vs. colon carcinomas with BRAF mutations. More conclusive data from basket trials and umbrella trials are needed [55].
Every effort should be made to form multidisciplinary teams involving radiologists, nuclear medicine specialists, pathologists, oncologists, systems biologists, molecular biologists, and data scientists. Tumors must be analyzed at the genetic, molecular, and clinical-radiological level, with integration and correlation of findings to ensure a holistic approach.

(2) To overcome tumor heterogeneity, research should be directed towards the search for central nodes, funnel factors, master regulator genes, and non-oncogene addictions [122, 147-149], in an attempt to confer therapeutic sensitivity. Regarding drug development in malignant tumors and current paradigms in cancer research, new agents include those that target cancer-related vulnerabilities in receptor tyrosine kinases and intracellular signaling pathways, epigenetics, metabolism, and nuclearcytoplasmic transport, among others. The study of the tumor immune microenvironment appears quite promising and includes treatment with immune checkpoint antibodies, with programmed death 1 (PD-1 and PDL-1) targeted agents, and novel immunotherapies. It is likely that combinations will be needed for most subtypes. Recent studies in solid cancers have highlighted the presence and relevance of immune heterogeneity and that intratumor heterogeneity may also influence the antitumor immune responses [150-152].

Several studies [153-160] have shown that the expression of factors such as 4EBP1 and EIF4E is diffuse in most solid tumors and glioblastomas and is associated with lower survival and poorer prognosis. We proposed the concept of funnel factors [80], that is, factors that channel crucial information on tumor progression independently of the level at which a specific oncogenic alteration occurs. These factors, which play a significant role in the control of protein synthesis, could be sensitive tumor targets in a large number of malignant tumors [79, $83,161,162]$.

Complex models that implement combinatorial therapy are likely to be particularly beneficial in tumors with a high degree of tumor heterogeneity. In this broad context, evolutionary clues and new findings on interclonal relationships should also be taken into account $[81,101,113$, 163]. The identification of factors involved in this interplay between malignant clones, which mediate tumor growth and metastasis, may be one promising approach in the understanding of cancer [101]. Therefore, studies carried out from the perspective of systems biology [149], tailored towards the identification of hubs or other central factors in this complicated tangle of biochemical networks responsible for maintaining the tumorigenic state, will be fundamental in the identification of addictions and 
vulnerabilities in cancer that would otherwise be difficult to imagine [147, 164].

(3) Liquid biopsies. Difficulties in obtaining tumor tissue using invasive surgical procedures have led to the development of liquid biopsies for several cancer types [165-184]. They comprise tumor-derived nucleic acids (e.g., circulating cell-free tumor DNA [ctDNA], microRNA), circulating tumor cells (CTCs), and tumor-derived extracellular vesicles that accumulate in the blood, cerebrospinal fluid (CSF), urine, saliva, and other fluids [165, 178, 185-191]. One advantage of liquid biopsies is that it significantly reduces the problem of spatial heterogeneity. Several studies, comparing blood and tissue biopsies, have confirmed that this approach has high specificity, although variable sensitivity is reported. Another important advantage (although under certain situations it may be a disadvantage) is that it tends to reflect an aggregate of the output (ctDNA/CTC etc.) potentially from both primary and various metastatic sites. Such complex tumor heterogeneity cannot be evaluated by a single core tumor needle biopsy [192].

However, the most clinically advanced approach is ctDNA from plasma which closely matches the gene profile of tumor tissue biopsies. Plasma ctDNA provides tumor-derived material to identify actionable genomic alterations, monitor treatment responses, predict progression of the tumor before clinical or radiological confirmation, and can identify mechanisms of resistance also during therapy $[173,174,176,193$, 194]. For a comprehensive review, see [195].

Prospective clinical studies using liquid biopsies have characterized and monitored over time the genomic alterations of patients $[40,174]$. Recently, the TRACERx consortium [7, 196] investigated tumor heterogeneity and evolution in early-stage NSCLC and showed the prognostic value of copy-number heterogeneity assessment in tumor biopsies and circulating tumor DNA detection in plasma. However, these liquid biopsy results reflect a kind of summary of tumor burden, regardless of the origin of the tumor cells (from primary or metastatic deposits), and require some degree of by-pass of microanatomical boundaries (vascular basement membrane and stromal invasion) by either active tumor invasion or passive external damage (e.g., ischemic or inflammatory). In this context, some caution should be taken for the evaluation of early epithelial neoplasms.

The role of subclonal driver events in response to therapy and disease recurrence and progression remains to be determined. The use of liquid biopsies may pave the way for a more detailed, real-time patient-tracking approach allowing the modification of therapeutic strategies throughout the disease.
(4) Artificial intelligence. Intratumor heterogeneity is one of the main reasons for the lack of diagnostic reproducibility between pathologists given the complexity of the microscopic interpretation of certain tumors. Furthermore, many biomarkers do not have an established interpretation algorithm. It is critical to improve existing algorithms for the quantification of immunohistochemical and other in situ biomarkers. The development of artificial intelligence algorithms with automatic learning ("deep learning") is already shaping the field. Deep learning methodology, with the generation of thousands of clinical-pathological diagnostic cases, can promote the development of algorithms based on this methodology that could represent a breakthrough in the pathological diagnosis As an example, Google released TensorFlow, an algorithmic development framework for distributed computing, to the general scientific and technical community. This open-source machine learning tool is free for any qualified scientist and is specialized in cognitive computing.

With this approach, software is being developed by many startups and educational institutions as well as big companies such as Google, Phillips and Leica Microsoft. Algorithmrelated applications for primary diagnosis, intraoperative diagnosis, training, quantification of immunohistochemistry, or diagnostic consultation are likely to progress significantly over the next few years. Notably, there have been several claims that the accuracy and reliability of diagnoses based on neural network systems is very high [197, 198]. Examples have been published for skin cancer (both melanoma and squamous cell carcinoma), lung adenocarcinoma, glioma, gastric carcinoma, and others [135, 199-202].

Moreover, the deep learning tumor prediction heat map can be quite complementary to pathologists" "workflow." An algorithm can detect, for example, metastatic carcinoma in lymph nodes, or tumor budding in the colon or cervix, and help to recognize histologic patterns associated with higher malignant grades in gliomas [203], and moreover, can score the degree of malignancy in tumors such a prostate adenocarcinomas where quantification of the histological patterns are underway [197, 198].

These algorithms are likely to help pathologists in reaching a faster, more accurate diagnosis and significantly reduce the pathologist-dependent discordance in histopathological diagnosis.

(5) As a final reflection, we firmly believe that research strategies should be optimized. At present, most research teams are small, self-managed groups. Consequently, research is slow, and financial and human resources are not optimized. We must establish more rational and ambitious organizational models and strategies, with real 
networks and professional, well-trained teams. As Horning recently said [204], "science and technology are at an inflection point with convergence - the integration of life sciences, physical sciences, mathematics, engineering, and information technology—poised to make significant progress". We must look forward and not forget that our primary objective is to cure cancer or at least make it a chronic disease. Such a social commitment requires us to search for all possible methods of cooperation among those involved in the diagnosis and treatment of cancer.

Funding information SRYC received support from Fondo de Investigaciones Sanitarias (PI14/01320 and PI17/02247), Redes Temáticas de Investigación Cooperativa en Salud (RD12/0036/0057), CIBERONC (CB16/12/00363), and Generalitat de Catalunya (AGAUR, 2017 SGR 1799 and 2014 SGR 1131). TA received support from Instituto de Salud Carlos III (grants PI16/00772 and CPII16/00042), co-financed by the European Regional Development Fund (ERDF).

\section{Compliance with ethical standards}

Conflict of interest The authors declare that they have no conflict of interest.

Open Access This article is licensed under a Creative Commons Attribution 4.0 International License, which permits use, sharing, adaptation, distribution and reproduction in any medium or format, as long as you give appropriate credit to the original author(s) and the source, provide a link to the Creative Commons licence, and indicate if changes were made. The images or other third party material in this article are included in the article's Creative Commons licence, unless indicated otherwise in a credit line to the material. If material is not included in the article's Creative Commons licence and your intended use is not permitted by statutory regulation or exceeds the permitted use, you will need to obtain permission directly from the copyright holder. To view a copy of this licence, visit http://creativecommons.org/licenses/by/4.0/.

\section{References}

1. Jamal-Hanjani M, Quezada SA, Larkin J, Swanton C (2015) Translational implications of tumor heterogeneity. Clin Cancer Res 21(6): 1258-1266

2. Marusyk A, Almendro V, Polyak K (2012) Intra-tumour heterogeneity: a looking glass for cancer? Nat Rev Cancer 12(5):323-334

3. Mroz EA, Rocco JW (2013) MATH, a novel measure of intratumor genetic heterogeneity, is high in poor-outcome classes of head and neck squamous cell carcinoma. Oral Oncol 49(3):211-215

4. Landau DA, Carter SL, Stojanov P, McKenna A, Stevenson K, Lawrence MS, Sougnez C, Stewart C, Sivachenko A, Wang L et al (2013) Evolution and impact of subclonal mutations in chronic lymphocytic leukemia. Cell 152(4):714-726

5. Zhang J, Fujimoto J, Wedge DC, Song X, Seth S, Chow CW, Cao Y, Gumbs C, Gold KA, Kalhor N et al (2014) Intratumor heterogeneity in localized lung adenocarcinomas delineated by multiregion sequencing. Science 346(6206):256-259

6. Patel AP, Tirosh I, Trombetta JJ, Shalek AK, Gillespie SM, Wakimoto H, Cahill DP, Nahed BV, Curry WT, Martuza RL et al (2014) Single-cell RNA-seq highlights intratumoral heterogeneity in primary glioblastoma. Science 344(6190):1396-1401

7. Jamal-Hanjani M, Wilson GA, McGranahan N, Birkbak NJ, Watkins TBK, Veeriah S, Shafi S, Johnson DH, Mitter R, Rosenthal $\mathrm{R}$ et al (2017) Tracking the evolution of non-smallcell lung cancer. N Engl J Med 376(22):2109-2121

8. McGranahan N, Favero F, de Bruin EC, Birkbak NJ, Szallasi Z, Swanton C (2015) Clonal status of actionable driver events and the timing of mutational processes in cancer evolution. Sci Transl Med 7(283):283ra254

9. McGranahan N, Swanton C (2017) Clonal heterogeneity and tumor evolution: past, present, and the future. Cell 168(4):613-628

10. Gomez-Martin C, Concha A, Corominas JM, Garcia-Caballero T, Garcia-Garcia E, Iglesias M, Lopez JA, Ramon y Cajal S, Rojo F, Palacios J et al (2011) Consensus of the Spanish Society of Medical Oncology (SEOM) and Spanish Society of Pathology (SEAP) for HER2 testing in gastric carcinoma. Clin Trans1 Oncol 13(9):636-651

11. Hammond ME, Hayes DF, Dowsett M, Allred DC, Hagerty KL, Badve S, Fitzgibbons PL, Francis G, Goldstein NS, Hayes M et al (2010) American Society of Clinical Oncology/College Of American Pathologists guideline recommendations for immunohistochemical testing of estrogen and progesterone receptors in breast cancer. J Clin Oncol 28(16):2784-2795

12. Abe H, Kawahara A, Azuma K, Taira T, Takase Y, Fukumitsu C, Murata K, Yamaguchi T, Akiba J, Ishii H et al (2015) Heterogeneity of anaplastic lymphoma kinase gene rearrangement in non-smallcell lung carcinomas: a comparative study between small biopsy and excision samples. J Thorac Oncol 10(5):800-805

13. Eckel-Passow JE, Lachance DH, Molinaro AM, Walsh KM, Decker PA, Sicotte H, Pekmezci M, Rice T, Kosel ML, Smirnov IV et al (2015) Glioma groups based on 1p/19q, IDH, and TERT promoter mutations in tumors. N Engl J Med 372(26):2499-2508

14. Fiskus W, Mitsiades N (2016) B-Raf inhibition in the clinic: present and future. Annu Rev Med 67:29-43

15. Travis WD, Brambilla E, Noguchi M, Nicholson AG, Geisinger K, Yatabe Y, Ishikawa Y, Wistuba I, Flieder DB, Franklin W et al (2013) Diagnosis of lung cancer in small biopsies and cytology: implications of the 2011 International Association for the Study of Lung Cancer/American Thoracic Society/European Respiratory Society classification. Arch Pathol Lab Med 137(5):668-684

16. O'Connor JP, Rose CJ, Waterton JC, Carano RA, Parker GJ, Jackson A (2015) Imaging intratumor heterogeneity: role in therapy response, resistance, and clinical outcome. Clin Cancer Res 21(2):249-257

17. Zhou M, Li J, Cheng L, Egevad L, Deng FM, Kunju LP, MagiGalluzzi C, Melamed J, Mehra R, Mendrinos S et al (2015) Diagnosis of "poorly formed glands" Gleason pattern 4 prostatic adenocarcinoma on needle biopsy: an interobserver reproducibility study among urologic pathologists with recommendations. Am J Surg Pathol 39(10):1331-1339

18. Park SY, Gonen M, Kim HJ, Michor F, Polyak K (2010) Cellular and genetic diversity in the progression of in situ human breast carcinomas to an invasive phenotype. J Clin Invest 120(2):636-644

19. Denisov EV, Litviakov NV, Zavyalova MV, Perelmuter VM, Vtorushin SV, Tsyganov MM, Gerashchenko TS, Garbukov EY, Slonimskaya EM, Cherdyntseva NV (2014) Intratumoral morphological heterogeneity of breast cancer: neoadjuvant chemotherapy efficiency and multidrug resistance gene expression. Sci Rep 4:4709

20. Seol H, Lee HJ, Choi Y, Lee HE, Kim YJ, Kim JH, Kang E, Kim SW, Park SY (2012) Intratumoral heterogeneity of HER2 gene amplification in breast cancer: its clinicopathological significance. Mod Pathol 25(7):938-948

21. McGranahan N, Swanton C (2015) Biological and therapeutic impact of intratumor heterogeneity in cancer evolution. Cancer Cell 27(1):15-26 
22. Sequist LV, Waltman BA, Dias-Santagata D, Digumarthy S, Turke AB, Fidias P, Bergethon K, Shaw AT, Gettinger S, Cosper AK et al (2011) Genotypic and histological evolution of lung cancers acquiring resistance to EGFR inhibitors. Sci Transl Med 3(75):75ra26

23. Chang F (2006) Desmoplastic small round cell tumors: cytologic, histologic, and immunohistochemical features. Arch Pathol Lab Med 130(5):728-732

24. Nielsen TO, Poulin NM, Ladanyi M (2015) Synovial sarcoma: recent discoveries as a roadmap to new avenues for therapy. Cancer Discov 5(2):124-134

25. Denisov EV, Skryabin NA, Vasilyev SA, Gerashchenko TS, Lebedev IN, Zavyalova MV, Cherdyntseva NV, Perelmuter VM (2015) Relationship between morphological and cytogenetic heterogeneity in invasive micropapillary carcinoma of the breast: a report of one case. J Clin Pathol 68(9):758-762

26. Zack TI, Schumacher SE, Carter SL, Cherniack AD, Saksena G, Tabak B, Lawrence MS, Zhsng CZ, Wala J, Mermel CH et al (2013) Pan-cancer patterns of somatic copy number alteration. Nat Genet 45(10):1134-1140

27. Mateo L, Guitart-Pla O, Pons C, Duran-Frigola M, Mosca R, Aloy $P$ (2017) A PanorOmic view of personal cancer genomes. Nucleic Acids Res 45(W1):W195-W200

28. Roychowdhury S, Chinnaiyan AM (2016) Translating cancer genomes and transcriptomes for precision oncology. CA Cancer J Clin 66(1):75-88

29. Weinstein JN, Collisson EA, Mills GB, Shaw KR, Ozenberger BA, Ellrott K, Shmulevich I, Sander C, Stuart JM (2013) The cancer genome atlas pan-cancer analysis project. Nat Genet 45(10):1113-1120

30. Lin S, Gregory RI (2015) MicroRNA biogenesis pathways in cancer. Nat Rev Cancer 15(6):321-333

31. Eriksen AH, Andersen RF, Nielsen BS, Sorensen FB, Appelt AL, Jakobsen A, Hansen TF (2016) Intratumoral heterogeneity of microRNA expression in rectal cancer. PLoS One 11(6): 0156919

32. Iyer MK, Niknafs YS, Malik R, Singhal U, Sahu A, Hosono Y, Barrette TR, Prensner JR, Evans JR, Zhao S et al (2015) The landscape of long noncoding RNAs in the human transcriptome. Nat Genet 47(3):199-208

33. Raychaudhuri M, Schuster T, Buchner T, Malinowsky K, Bronger H, Schwarz-Boeger U, Hofler H, Avril S (2012) Intratumoral heterogeneity of microRNA expression in breast cancer. J Mol Diagn 14(4):376-384

34. Ramon YCS, Segura MF, Hummer S (2019) Interplay between ncRNAs and cellular communication: a proposal for understanding cell-specific signaling pathways. Front Genet 10:281

35. Argani P, Fritsch M, Kadkol SS, Schuster A, Beckwith JB, Perlman EJ (2000) Detection of the ETV6-NTRK3 chimeric RNA of infantile fibrosarcoma/cellular congenital mesoblastic nephroma in paraffin-embedded tissue: application to challenging pediatric renal stromal tumors. Mod Pathol 13(1):29-36

36. Taylor BS, Barretina J, Maki RG, Antonescu CR, Singer S, Ladanyi M (2011) Advances in sarcoma genomics and new therapeutic targets. Nat Rev Cancer 11(8):541-557

37. Cantile M, Marra L, Franco R, Ascierto P, Liguori G, De Chiara A, Botti G (2013) Molecular detection and targeting of EWSR1 fusion transcripts in soft tissue tumors. Med Oncol 30(1):412

38. Hall RD, Kudchadkar RR (2014) BRAF mutations: signaling, epidemiology, and clinical experience in multiple malignancies. Cancer Control 21(3):221-230

39. Penman CL, Faulkner C, Lowis SP, Kurian KM (2015) Current understanding of BRAF alterations in diagnosis, prognosis, and therapeutic targeting in pediatric low-grade gliomas. Front Oncol 5:54

40. Karachaliou N, Mayo-delas Casas C, Queralt C, de Aguirre I, Melloni B, Cardenal F, Garcia-Gomez R, Massuti B, Sanchez JM, Porta R et al (2015) Association of EGFR L858R mutation in circulating free DNA with survival in the EURTAC trial. JAMA Oncol 1(2):149-157

41. Sharma P, Debinski W (2018) Receptor-targeted glial brain tumor therapies. Int J Mol Sci 19(11)

42. Skoulidis F, Heymach JV (2019) Co-occurring genomic alterations in non-small-cell lung cancer biology and therapy. Nat Rev Cancer 19(9):495-509

43. Ramon y Cajal S, Suster S, Halaban R, Filvaroff E, Dotto GP (1991) Induction of different morphologic features of malignant melanoma and pigmented lesions after transformation of murine melanocytes with bFGF-cDNA and H-ras, myc, neu, and E1a oncogenes. Am J Pathol 138(2):349-358

44. Sanchez-Prieto R, Lleonart M, Ramon y Cajal S (1995) Lack of correlation between $\mathrm{p} 53$ protein level and sensitivity of DNAdamaging agents in keratinocytes carrying adenovirus E1a mutants. Oncogene 11(4):675-682

45. Sanchez-Prieto R, Vargas JA, Carnero A, Marchetti E, Romero J, Durantez A, Lacal JC, Ramon y Cajal S (1995) Modulation of cellular chemoresistance in keratinocytes by activation of different oncogenes. Int J Cancer 60(2):235-243

46. Sanchez-Prieto R, Quintanilla M, Cano A, Leonart ML, Martin P, Anaya A, Ramon y Cajal S (1996) Carcinoma cell lines become sensitive to DNA-damaging agents by the expression of the adenovirus E1A gene. Oncogene 13(5):1083-1092

47. Duque PM, Alonso C, Sanchez-Prieto R, Quintanilla M, Ramon S, Ramon y Cajal S (1998) Antitumoral effect of E1B defective adenoviruses in human malignant cells. Gene Ther 5(2):286-287

48. Hanahan D, Weinberg RA (2000) The hallmarks of cancer. Cell 100(1):57-70

49. Hanahan D, Weinberg RA (2011) Hallmarks of cancer: the next generation. Cell 144(5):646-674

50. Maddipati R, Stanger BZ (2015) Pancreatic cancer metastases harbor evidence of polyclonality. Cancer Discov 5(10):1086-1097

51. Hong MK, Macintyre G, Wedge DC, Van Loo P, Patel K, Lunke S, Alexandrov LB, Sloggett C, Cmero M, Marass F et al (2015) Tracking the origins and drivers of subclonal metastatic expansion in prostate cancer. Nat Commun 6:6605

52. Dagogo-Jack I, Shaw AT (2018) Tumour heterogeneity and resistance to cancer therapies. Nat Rev Clin Oncol 15(2):81-94

53. Andor N, Graham TA, Jansen M, Xia LC, Aktipis CA, Petritsch C, Ji HP, Maley CC (2016) Pan-cancer analysis of the extent and consequences of intratumor heterogeneity. Nat Med 22(1):105113

54. Logue JS, Morrison DK (2012) Complexity in the signaling network: insights from the use of targeted inhibitors in cancer therapy. Genes Dev 26(7):641-650

55. Ramon YCS, Hummer S, Peg V, Matias Guiu X, De Torres I, Castellvi J, Martinez-Saez E, Hernandez-Losa J (2019) Integrating clinical, molecular, proteomic and histopathological data within the tissue context: Tissunomics. Histopathology. https://doi.org/10.1111/his.13828

56. Ramon YCS, Castellvi J, Hummer S, Peg V, Pelletier J, Sonenberg $\mathrm{N}$ (2018) Beyond molecular tumor heterogeneity: protein synthesis takes control. Oncogene 37(19):2490-2501

57. Kumar R, Liu APY, Orr BA, Northcott PA, Robinson GW (2018) Advances in the classification of pediatric brain tumors through DNA methylation profiling: from research tool to frontline diagnostic. Cancer 124(21):4168-4180

58. Dong N, Shi L, Wang DC, Chen C, Wang X (2017) Role of epigenetics in lung cancer heterogeneity and clinical implication. Semin Cell Dev Biol 64:18-25

59. Bhawal UK, Tsukinoki K, Sasahira T, Sato F, Mori Y, Muto N, Sugiyama M, Kuniyasu H (2007) Methylation and intratumoural heterogeneity of 14-3-3 sigma in oral cancer. Oncol Rep 18(4): $817-824$ 
60. Agarwal R, Narayan J, Bhattacharyya A, Saraswat M, Tomar AK (2017) Gene expression profiling, pathway analysis and subtype classification reveal molecular heterogeneity in hepatocellular carcinoma and suggest subtype specific therapeutic targets. Cancer Genet 216-217:37-51

61. Assenov Y, Brocks D, Gerhauser C (2018) Intratumor heterogeneity in epigenetic patterns. Semin Cancer Biol 51:12-21

62. Yuan Y, Jiang YC, Sun CK, Chen QM (2016) Role of the tumor microenvironment in tumor progression and the clinical applications (review). Oncol Rep 35(5):2499-2515

63. Devarakonda S, Morgensztern D, Govindan R (2015) Genomic alterations in lung adenocarcinoma. Lancet Oncol 16(7):e342e351

64. Hinoue T, Weisenberger DJ, Lange CP, Shen H, Byun HM, Van Den Berg D, Malik S, Pan F, Noushmehr H, van Dijk CM et al (2012) Genome-scale analysis of aberrant DNA methylation in colorectal cancer. Genome Res 22(2):271-282

65. Lobo J, Barros-Silva D, Henrique R, Jeronimo C (2018) The emerging role of Epitranscriptomics in Cancer: focus on urological tumors. Genes (Basel) 9(11)

66. Tomasetti C, Marchionni L, Nowak MA, Parmigiani G, Vogelstein B (2015) Only three driver gene mutations are required for the development of lung and colorectal cancers. Proc Natl Acad Sci U S A 112(1):118-123

67. Vogelstein B, Kinzler KW (2015) The path to cancer-three strikes and you're out. N Engl J Med 373(20):1895-1898

68. Sehgal R, Sheahan K, O'Connell PR, Hanly AM, Martin ST, Winter DC (2014) Lynch syndrome: an updated review. Genes (Basel) 5(3):497-507

69. Blanes A, Diaz-Cano SJ (2006) Complementary analysis of microsatellite tumor profile and mismatch repair defects in colorectal carcinomas. World J Gastroenterol 12(37):5932-5940

70. Diaz-Cano SJ (2008) General morphological and biological features of neoplasms: integration of molecular findings. Histopathology 53(1):1-19

71. Yang Q, Yang Y, Zhou N, Tang K, Lau WB, Lau B, Wang W, Xu L, Yang Z, Huang S et al (2018) Epigenetics in ovarian cancer: premise, properties, and perspectives. Mol Cancer 17(1):109

72. Shen H, Laird PW (2013) Interplay between the cancer genome and epigenome. Cell 153(1):38-55

73. Rastetter M, Schagdarsurengin U, Lahtz C, Fiedler E, Marsch W, Dammann R, Helmbold P (2007) Frequent intra-tumoural heterogeneity of promoter hypermethylation in malignant melanoma. Histol Histopathol 22(9):1005-1015

74. Korshunova Y, Maloney RK, Lakey N, Citek RW, Bacher B, Budiman A, Ordway JM, McCombie WR, Leon J, Jeddeloh JA et al (2008) Massively parallel bisulphite pyrosequencing reveals the molecular complexity of breast cancer-associated cytosinemethylation patterns obtained from tissue and serum DNA. Genome Res 18(1):19-29

75. Varley KE, Mutch DG, Edmonston TB, Goodfellow PJ, Mitra RD (2009) Intra-tumor heterogeneity of MLH1 promoter methylation revealed by deep single molecule bisulfite sequencing. Nucleic Acids Res 37(14):4603-4612

76. Moelans CB, Verschuur-Maes AH, van Diest PJ (2011) Frequent promoter hypermethylation of BRCA2, CDH13, MSH6, PAX5, PAX6 and WT1 in ductal carcinoma in situ and invasive breast cancer. J Pathol 225(2):222-231

77. De Carvalho DD, Sharma S, You JS, Su SF, Taberlay PC, Kelly TK, Yang X, Liang G, Jones PA (2012) DNA methylation screening identifies driver epigenetic events of cancer cell survival. Cancer Cell 21(5):655-667

78. Brocks D, Assenov Y, Minner S, Bogatyrova O, Simon R, Koop C, Oakes C, Zucknick M, Lipka DB, Weischenfeldt J et al (2014) Intratumor DNA methylation heterogeneity reflects clonal evolution in aggressive prostate cancer. Cell Rep 8(3):798-806
79. Castellvi J, Garcia A, Rojo F, Ruiz-Marcellan C, Gil A, Baselga J, Ramon y Cajal S (2006) Phosphorylated 4E binding protein 1: a hallmark of cell signaling that correlates with survival in ovarian cancer. Cancer 107(8):1801-1811

80. Armengol G, Rojo F, Castellvi J, Iglesias C, Cuatrecasas M, Pons B, Baselga J, Ramon y Cajal S (2007) 4E-binding protein 1: a key molecular "funnel factor" in human cancer with clinical implications. Cancer Res 67(16):7551-7555

81. Pons B, Peg V, Vazquez-Sanchez MA, Lopez-Vicente L, Argelaguet E, Coch L, Martinez A, Hernandez-Losa J, Armengol G, Ramon YCS (2011) The effect of p-4E-BP1 and p-eIF4E on cell proliferation in a breast cancer model. Int $J$ Oncol 39(5):1337-1345

82. Serrano C, Romagosa C, Hernandez-Losa J, Simonetti S, Valverde C, Moline T, Somoza R, Perez M, Velez R, Verges R et al (2016) RAS/MAPK pathway hyperactivation determines poor prognosis in undifferentiated pleomorphic sarcomas. Cancer 122(1):99-107

83. Martinez A, Sese M, Losa JH, Robichaud N, Sonenberg N, Aasen T, Ramon YCS (2015) Phosphorylation of eIF4E confers resistance to cellular stress and DNA-damaging agents through an interaction with 4E-T: a rationale for novel therapeutic approaches. PLoS One 10(4):e0123352

84. Gerdes MJ, Sood A, Sevinsky C, Pris AD, Zavodszky MI, Ginty F (2014) Emerging understanding of multiscale tumor heterogeneity. Front Oncol 4:366

85. Ramon YCS, De Mattos-Arruda L, Sonenberg N, Cortes J, Peg V (2014) The intra-tumor heterogeneity of cell signaling factors in breast cancer: p4E-BP1 and peIF4E are diffusely expressed and are real potential targets. Clin Transl Oncol 16(11):937-941

86. Gahete MD, Cordoba-Chacon J, Hergueta-Redondo M, MartinezFuentes AJ, Kineman RD, Moreno-Bueno G, Luque RM, Castano JP (2011) A novel human ghrelin variant (In1-ghrelin) and ghrelin-O-acyltransferase are overexpressed in breast cancer: potential pathophysiological relevance. PLoS One 6(8):e23302

87. Inoue K, Fry EA (2015) Aberrant splicing of estrogen receptor, HER2, and CD44 genes in breast cancer. Genet Epigenet 7:19-32

88. Castellana B, Aasen T, Moreno-Bueno G, Dunn SE, Ramon y Cajal S (2015) Interplay between YB-1 and IL-6 promotes the metastatic phenotype in breast cancer cells. Oncotarget 6(35): 38239-38256

89. Silvera D, Formenti SC, Schneider RJ (2010) Translational control in cancer. Nat Rev Cancer 10(4):254-266

90. Ramon y Cajal S, Missero C, Marchetti E, Dotto GP (1994) Dermal fibroblasts tumor suppression of ras-transformed keratinocytes is associated with induction of squamous cell differentiation. Am J Pathol 145(4):846-855

91. Dotto GP, Weinberg RA, Ariza A (1988) Malignant transformation of mouse primary keratinocytes by Harvey sarcoma virus and its modulation by surrounding normal cells. Proc Natl Acad Sci U S A 85(17):6389-6393

92. Perez-Villamil B, Romera-Lopez A, Hernandez-Prieto S, LopezCampos G, Calles A, Lopez-Asenjo JA, Sanz-Ortega J, Fernandez-Perez C, Sastre J, Alfonso R et al (2012) Colon cancer molecular subtypes identified by expression profiling and associated to stroma, mucinous type and different clinical behavior. BMC Cancer 12:260

93. Calon A, Lonardo E, Berenguer-Llergo A, Espinet E, HernandoMomblona X, Iglesias M, Sevillano M, Palomo-Ponce S, Tauriello DV, Byrom D et al (2015) Stromal gene expression defines poor-prognosis subtypes in colorectal cancer. Nat Genet 47(4):320-329

94. Zhang S, Jing Y, Zhang M, Zhang Z, Ma P, Peng H, Shi K, Gao WQ, Zhuang G (2015) Stroma-associated master regulators of molecular subtypes predict patient prognosis in ovarian cancer. Sci Rep 5:16066 
95. Wang WQ, Liu L, Xu HX, Luo GP, Chen T, Wu CT, Xu YF, Xu J, Liu C, Zhang B et al (2013) Intratumoral alpha-SMA enhances the prognostic potency of CD34 associated with maintenance of microvessel integrity in hepatocellular carcinoma and pancreatic cancer. PLoS One 8(8):e71189

96. Dotto GP (2014) Multifocal epithelial tumors and field cancerization: stroma as a primary determinant. J Clin Invest 124(4):1446-1453

97. Meacham CE, Morrison SJ (2013) Tumour heterogeneity and cancer cell plasticity. Nature 501(7467):328-337

98. Bissell MJ, Labarge MA (2005) Context, tissue plasticity, and cancer: are tumor stem cells also regulated by the microenvironment? Cancer Cell 7(1):17-23

99. Polyak K (2011) Heterogeneity in breast cancer. J Clin Invest 121(10):3786-3788

100. Polyak K, Haviv I, Campbell IG (2009) Co-evolution of tumor cells and their microenvironment. Trends Genet 25(1):30-38

101. Ramon YCS, Capdevila C, Hernandez-Losa J, De Mattos-Arruda L, Ghosh A, Lorent J, Larsson O, Aasen T, Postovit LM, Topisirovic I (2017) Cancer as an ecomolecular disease and a neoplastic consortium. Biochim Biophys Acta 1868(2):484-499

102. Chapman A, Fernandez del Ama L, Ferguson J, Kamarashev J, Wellbrock C, Hurlstone A (2014) Heterogeneous tumor subpopulations cooperate to drive invasion. Cell Rep 8(3):688-695

103. Cheung KJ, Padmanaban V, Silvestri V, Schipper K, Cohen JD, Fairchild AN, Gorin MA, Verdone JE, Pienta KJ, Bader JS et al (2016) Polyclonal breast cancer metastases arise from collective dissemination of keratin 14-expressing tumor cell clusters. Proc Natl Acad Sci U S A 113(7):E854-E863

104. Aceto N, Bardia A, Miyamoto DT, Donaldson MC, Wittner BS, Spencer JA, Yu M, Pely A, Engstrom A, Zhu H et al (2014) Circulating tumor cell clusters are oligoclonal precursors of breast cancer metastasis. Cell 158(5):1110-1122

105. Cheung KJ, Gabrielson E, Werb Z, Ewald AJ (2013) Collective invasion in breast cancer requires a conserved basal epithelial program. Cell 155(7):1639-1651

106. Martin-Pardillos A, Valls Chiva A, Bande Vargas G, Hurtado Blanco P, Pineiro Cid R, Guijarro PJ, Hummer S, Bejar Serrano E, Rodriguez-Casanova A, Diaz-Lagares A et al (2019) The role of clonal communication and heterogeneity in breast cancer. BMC Cancer 19(1):666

107. Keith B, Johnson RS, Simon MC (2011) HIF1alpha and HIF2alpha: sibling rivalry in hypoxic tumour growth and progression. Nat Rev Cancer 12(1):9-22

108. Turajlic S, Swanton C (2016) Metastasis as an evolutionary process. Science 352(6282):169-175

109. Notta F, Mullighan CG, Wang JC, Poeppl A, Doulatov S, Phillips LA, Ma J, Minden MD, Downing JR, Dick JE (2011) Evolution of human BCR-ABL1 lymphoblastic leukaemia-initiating cells. Nature 469(7330):362-367

110. Ding L, Ley TJ, Larson DE, Miller CA, Koboldt DC, Welch JS, Ritchey JK, Young MA, Lamprecht T, McLellan MD et al (2012) Clonal evolution in relapsed acute myeloid leukaemia revealed by whole-genome sequencing. Nature 481(7382):506-510

111. Janiszewska M, Liu L, Almendro V, Kuang Y, Paweletz C, Sakr RA, Weigelt B, Hanker AB, Chandarlapaty S, King TA et al (2015) In situ single-cell analysis identifies heterogeneity for PIK3CA mutation and HER2 amplification in HER2-positive breast cancer. Nat Genet 47(10):1212-1219

112. Bouwman P, Jonkers J (2014) Molecular pathways: how can BRCA-mutated tumors become resistant to PARP inhibitors? Clin Cancer Res 20(3):540-547

113. Marusyk A, Tabassum DP, Altrock PM, Almendro V, Michor F, Polyak K (2014) Non-cell-autonomous driving of tumour growth supports sub-clonal heterogeneity. Nature 514(7520):54-58
114. Krook MA, Chen HZ, Bonneville R, Allenby P, Roychowdhury S (2019) Rapid research autopsy: piecing the puzzle of tumor heterogeneity. Trends Cancer 5(1):1-5

115. Bedard PL, Hansen AR, Ratain MJ, Siu LL (2013) Tumour heterogeneity in the clinic. Nature 501(7467):355-364

116. Siegel MB, He X, Hoadley KA, Hoyle A, Pearce JB, Garrett AL, Kumar S, Moylan VJ, Brady CM, Van Swearingen AE et al (2018) Integrated RNA and DNA sequencing reveals early drivers of metastatic breast cancer. J Clin Invest 128(4):1371-1383

117. Hoadley KA, Siegel MB, Kanchi KL, Miller CA, Ding L, Zhao W, He X, Parker JS, Wendl MC, Fulton RS et al (2016) Tumor evolution in two patients with basal-like breast cancer: a retrospective genomics study of multiple metastases. PLoS Med 13(12): e1002174

118. Hoadley KA, Siegel MB, Kanchi KL, Miller CA, Ding L, Zhao W, He X, Parker JS, Wendl MC, Fulton RS et al (2017) Correction: tumor evolution in two patients with basal-like breast cancer: a retrospective genomics study of multiple metastases. PLoS Med 14(1):e1002222

119. Mattos-Arruda LD, Sammut S-J, Ross EM, Bashford-Rogers R, Greenstein E, Morganella S, Rueda OM, Martinez-Saez E, Peg V, Cortés J et al (2018) The integrated genomic and immune landscapes of lethal metastatic breast cancer (MBC). J Clin Oncol 36(15_suppl):1009-1009

120. Tabernero J, Lenz HJ, Siena S, Sobrero A, Falcone A, Ychou M, Humblet Y, Bouche O, Mineur L, Barone C et al (2015) Analysis of circulating DNA and protein biomarkers to predict the clinical activity of regorafenib and assess prognosis in patients with metastatic colorectal cancer: a retrospective, exploratory analysis of the CORRECT trial. Lancet Oncol 16(8):937-948

121. Malladi S, Macalinao DG, Jin X, He L, Basnet H, Zou Y, de Stanchina E, Massague J (2016) Metastatic latency and immune evasion through autocrine inhibition of WNT. Cell 165(1):45-60

122. Paul JM, Templeton SD, Baharani A, Freywald A, Vizeacoumar FJ (2014) Building high-resolution synthetic lethal networks: a 'Google map' of the cancer cell. Trends Mol Med 20(12):704-715

123. Blanes A, Diaz-Cano SJ (2006) DNA and kinetic heterogeneity during the clonal evolution of adrenocortical proliferative lesions. Hum Pathol 37(10):1295-1303

124. Blanes A, Rubio J, Martinez A, Wolfe HJ, Diaz-Cano SJ (2002) Kinetic profiles by topographic compartments in muscle-invasive transitional cell carcinomas of the bladder: role of TP53 and NF1 genes. Am J Clin Pathol 118(1):93-100

125. Blanes A, Rubio J, Sanchez-Carrillo JJ, Diaz-Cano SJ (2009) Coexistent intraurothelial carcinoma and muscle-invasive urothelial carcinoma of the bladder: clonality and somatic downregulation of DNA mismatch repair. Hum Pathol 40(7):988-997

126. Blanes A, Sanchez-Carrillo JJ, Diaz-Cano SJ (2006) Topographic molecular profile of pheochromocytomas: role of somatic downregulation of mismatch repair. J Clin Endocrinol Metab 91(3): $1150-1158$

127. Diaz-Cano SJ (2007) Kinetic topographical heterogeneity in follicular thyroid neoplasms and growth patterns. Histopathology 51(3):416-418

128. Diaz-Cano SJ, Blanes A, Rubio J, Matilla A, Wolfe HJ (2000) Molecular evolution and intratumor heterogeneity by topographic compartments in muscle-invasive transitional cell carcinoma of the urinary bladder. Lab Investig 80(3):279-289

129. Pozo L, Sanchez-Carrillo JJ, Martinez A, Blanes A, Diaz-Cano SJ (2007) Differential kinetic features by tumour topography in cutaneous small-cell neuroendocrine (Merkel cell) carcinomas. J Eur Acad Dermatol Venereol 21(9):1220-1228

130. Diaz-Cano SJ (2000) Designing a molecular analysis of clonality in tumours. J Pathol 191(4):343-344

131. Diaz-Cano SJ (2001) Are PCR artifacts in microdissected samples preventable? Hum Pathol 32(12):1415-1416 
132. Diaz-Cano SJ, Blanes A, Wolfe HJ (2001) PCR techniques for clonality assays. Diagn Mol Pathol 10(1):24-33

133. Nakamura T, Kuwai T, Kitadai Y, Sasaki T, Fan D, Coombes KR, Kim SJ, Fidler IJ (2007) Zonal heterogeneity for gene expression in human pancreatic carcinoma. Cancer Res 67(16):7597-7604

134. Gonzalez-Garcia I, Sole RV, Costa J (2002) Metapopulation dynamics and spatial heterogeneity in cancer. Proc Natl Acad Sci U S A 99(20):13085-13089

135. Romo-Bucheli D, Janowczyk A, Gilmore H, Romero E, Madabhushi A (2017) A deep learning based strategy for identifying and associating mitotic activity with gene expression derived risk categories in estrogen receptor positive breast cancers. Cytometry A 91(6):566-573

136. Heng YJ, Lester SC, Tse GM, Factor RE, Allison KH, Collins LC, Chen YY, Jensen KC, Johnson NB, Jeong JC et al (2017) The molecular basis of breast cancer pathological phenotypes. J Pathol 241(3):375-391

137. Trinh A, Trumpi K, De Sousa EMF, Wang X, de Jong JH, Fessler E, Kuppen PJ, Reimers MS, Swets M, Koopman M et al (2017) Practical and robust identification of molecular subtypes in colorectal cancer by immunohistochemistry. Clin Cancer Res 23(2): 387-398

138. Louis DN, Perry A, Burger P, Ellison DW, Reifenberger G, von Deimling A, Aldape K, Brat D, Collins VP, Eberhart C et al (2014) International society of neuropathology-Haarlem consensus guidelines for nervous system tumor classification and grading. Brain Pathol 24(5):429-435

139. Yamamoto S, Maki DD, Korn RL, Kuo MD (2012) Radiogenomic analysis of breast cancer using MRI: a preliminary study to define the landscape. AJR Am J Roentgenol 199(3):654-663

140. Jamshidi N, Jonasch E, Zapala M, Korn RL, Brooks JD, Ljungberg B, Kuo MD (2016) The radiogenomic risk score stratifies outcomes in a renal cell cancer phase 2 clinical trial. Eur Radiol 26(8):2798-2807

141. Eberwine J, Sul JY, Bartfai T, Kim J (2014) The promise of singlecell sequencing. Nat Methods 11(1):25-27

142. Chappell L, Russell AJC, Voet T (2018) Single-cell (multi)omics technologies. Annu Rev Genomics Hum Genet 19:15-41

143. Dal Molin A, Di Camillo B (2018) How to design a single-cell RNA-sequencing experiment: pitfalls, challenges and perspectives. Brief Bioinform. https://doi.org/10.1093/bib/bby007

144. Zeng T, Dai H (2019) Single-cell RNA sequencing-based computational analysis to describe disease heterogeneity. Front Genet 10:629

145. Cao J, Packer JS, Ramani V, Cusanovich DA, Huynh C, Daza R, Qiu X, Lee C, Furlan SN, Steemers FJ et al (2017) Comprehensive single-cell transcriptional profiling of a multicellular organism. Science 357(6352):661-667

146. Dai W, Zhou F, Tang D, Lin L, Zou C, Tan W, Dai Y (2019) Single-cell transcriptional profiling reveals the heterogenicity in colorectal cancer. Medicine (Baltimore) 98(34):e16916

147. Luo J, Solimini NL, Elledge SJ (2009) Principles of cancer therapy: oncogene and non-oncogene addiction. Cell 136(5):823-837

148. Khirade MF, Lal G, Bapat SA (2015) Derivation of a fifteen gene prognostic panel for six cancers. Sci Rep 5:13248

149. Werner HM, Mills GB, Ram PT (2014) Cancer systems biology: a peek into the future of patient care? Nat Rev Clin Oncol 11(3): $167-176$

150. Gerlinger M, Quezada SA, Peggs KS, Furness AJ, Fisher R, Marafioti T, Shende VH, McGranahan N, Rowan AJ, Hazell S et al (2013) Ultra-deep $\mathrm{T}$ cell receptor sequencing reveals the complexity and intratumour heterogeneity of T cell clones in renal cell carcinomas. J Pathol 231(4):424-432

151. Reuben A, Spencer CN, Prieto PA, Gopalakrishnan V, Reddy SM, Miller JP, Mao X, De Macedo MP, Chen J, Song X et al (2017) Genomic and immune heterogeneity are associated with differential responses to therapy in melanoma. NPJ Genom Med 2
152. Jimenez-Sanchez A, Memon D, Pourpe S, Veeraraghavan H, Li Y, Vargas HA, Gill MB, Park KJ, Zivanovic O, Konner J et al (2017) Heterogeneous tumor-immune microenvironments among differentially growing metastases in an ovarian cancer patient. Cell 170(5):927-938 e920

153. Graff JR, Konicek BW, Carter JH, Marcusson EG (2008) Targeting the eukaryotic translation initiation factor 4E for cancer therapy. Cancer Res 68(3):631-634

154. Graff JR, Konicek BW, Lynch RL, Dumstorf CA, Dowless MS, McNulty AM, Parsons SH, Brail LH, Colligan BM, Koop JW et al (2009) eIF4E activation is commonly elevated in advanced human prostate cancers and significantly related to reduced patient survival. Cancer Res 69(9):3866-3873

155. Fan S, Ramalingam SS, Kauh J, Xu Z, Khuri FR, Sun SY (2009) Phosphorylated eukaryotic translation initiation factor 4 (eIF4E) is elevated in human cancer tissues. Cancer Biol Ther 8(15):14631469

156. Yoshizawa A, Fukuoka J, Shimizu S, Shilo K, Franks TJ, Hewitt SM, Fujii T, Cordon-Cardo C, Jen J, Travis WD (2010) Overexpression of phospho-eIF4E is associated with survival through AKT pathway in non-small cell lung cancer. Clin Cancer Res 16(1):240-248

157. Campbell L, Jasani B, Griffiths DF, Gumbleton M (2015) Phospho-4e-BP1 and eIF4E overexpression synergistically drives disease progression in clinically confined clear cell renal cell carcinoma. Am J Cancer Res 5(9):2838-2848

158. Siddiqui N, Sonenberg N (2015) Signalling to eIF4E in cancer. Biochem Soc Trans 43(5):763-772

159. Pettersson F, Del Rincon SV, Emond A, Huor B, Ngan E, Ng J, Dobocan MC, Siegel PM, Miller WH Jr (2015) Genetic and pharmacologic inhibition of eIF4E reduces breast cancer cell migration, invasion, and metastasis. Cancer Res 75(6):1102-1112

160. Musa J, Orth MF, Dallmayer M, Baldauf M, Pardo C, Rotblat B, Kirchner T, Leprivier G, Grunewald TG (2016) Eukaryotic initiation factor 4E-binding protein 1 (4E-BP1): a master regulator of mRNA translation involved in tumorigenesis. Oncogene 35(36): 4675-4688

161. Topisirovic I, Sonenberg N (2015) Translation and cancer. Biochim Biophys Acta 1849(7):751-752

162. Rojo F, Najera L, Lirola J, Jimenez J, Guzman M, Sabadell MD, Baselga J, Ramon y Cajal S (2007) 4E-binding protein 1, a cell signaling hallmark in breast cancer that correlates with pathologic grade and prognosis. Clin Cancer Res 13(1):81-89

163. Tabassum DP, Polyak K (2015) Tumorigenesis: it takes a village. Nat Rev Cancer 15(8):473-483

164. Solimini NL, Luo J, Elledge SJ (2007) Non-oncogene addiction and the stress phenotype of cancer cells. Cell 130(6):986-988

165. Best MG, Sol N, Zijl S, Reijneveld JC, Wesseling P, Wurdinger T (2015) Liquid biopsies in patients with diffuse glioma. Acta Neuropathol 129(6):849-865

166. De Mattos-Arruda L, Caldas C (2015) Cell-free circulating tumour DNA as a liquid biopsy in breast cancer. Mol Oncol. https://doi. org/10.1016/j.molonc.2015.12.001

167. Alix-Panabieres C, Pantel K (2016) Clinical applications of circulating tumor cells and circulating tumor DNA as liquid biopsy. Cancer Discov. https://doi.org/10.1158/2159-8290.CD-15-1483

168. De Mattos-Arruda L, Cortes J, Santarpia L, Vivancos A, Tabernero J, Reis-Filho JS, Seoane J (2013) Circulating tumour cells and cell-free DNA as tools for managing breast cancer. Nat Rev Clin Oncol 10(7):377-389

169. Leary RJ, Kinde I, Diehl F, Schmidt K, Clouser C, Duncan C, Antipova A, Lee C, McKernan K, De La Vega FM et al (2010) Development of personalized tumor biomarkers using massively parallel sequencing. Sci Transl Med 2(20):20ra14

170. Leary RJ, Sausen M, Kinde I, Papadopoulos N, Carpten JD, Craig D, O'Shaughnessy J, Kinzler KW, Parmigiani G, Vogelstein B et al 
(2012) Detection of chromosomal alterations in the circulation of cancer patients with whole-genome sequencing. Sci Transl Med 4(162):162ra154

171. Forshew T, Murtaza M, Parkinson C, Gale D, Tsui DW, Kaper F, Dawson SJ, Piskorz AM, Jimenez-Linan M, Bentley D et al (2012) Noninvasive identification and monitoring of cancer mutations by targeted deep sequencing of plasma DNA. Sci Transl Med 4(136): 136ra168

172. Murtaza M, Dawson SJ, Tsui DW, Gale D, Forshew T, Piskorz AM, Parkinson C, Chin SF, Kingsbury Z, Wong AS et al (2013) Non-invasive analysis of acquired resistance to cancer therapy by sequencing of plasma DNA. Nature 497(7447):108-112

173. Dawson SJ, Tsui DW, Murtaza M, Biggs H, Rueda OM, Chin SF, Dunning MJ, Gale D, Forshew T, Mahler-Araujo B et al (2013) Analysis of circulating tumor DNA to monitor metastatic breast cancer. N Engl J Med 368(13):1199-1209

174. De Mattos-Arruda L, Weigelt B, Cortes J, Won HH, Ng CK, Nuciforo P, Bidard FC, Aura C, Saura C, Peg V et al (2014) Capturing intra-tumor genetic heterogeneity by de novo mutation profiling of circulating cell-free tumor DNA: a proof-of-principle. Ann Oncol 25(9):1729-1735

175. Rothe F, Laes JF, Lambrechts D, Smeets D, Vincent D, Maetens M, Fumagalli D, Michiels S, Drisis S, Moerman C et al (2014) Plasma circulating tumor DNA as an alternative to metastatic biopsies for mutational analysis in breast cancer. Ann Oncol 25(10): 1959-1965

176. Bettegowda C, Sausen M, Leary RJ, Kinde I, Wang Y, Agrawal N, Bartlett BR, Wang H, Luber B, Alani RM et al (2014) Detection of circulating tumor DNA in early- and late-stage human malignancies. Sci Transl Med 6(224):224ra224

177. Olsson E, Winter C, George A, Chen Y, Howlin J, Tang MH, Dahlgren M, Schulz R, Grabau D, van Westen D et al (2015) Serial monitoring of circulating tumor DNA in patients with primary breast cancer for detection of occult metastatic disease. EMBO Mol Med. https://doi.org/10.15252/emmm.201404913

178. De Mattos-Arruda L, Mayor R, Ng CK, Weigelt B, MartinezRicarte F, Torrejon D, Oliveira M, Arias A, Raventos C, Tang J et al (2015) Cerebrospinal fluid-derived circulating tumour DNA better represents the genomic alterations of brain tumours than plasma. Nat Commun 6:8839

179. Murtaza M, Dawson SJ, Pogrebniak K, Rueda OM, Provenzano E, Grant J, Chin SF, Tsui DW, Marass F, Gale D et al (2015) Multifocal clonal evolution characterized using circulating tumour DNA in a case of metastatic breast cancer. Nat Commun 6:8760

180. Newman AM, Bratman SV, To J, Wynne JF, Eclov NC, Modlin LA, Liu CL, Neal JW, Wakelee HA, Merritt RE et al (2014) An ultrasensitive method for quantitating circulating tumor DNA with broad patient coverage. Nat Med 20(5):548-554

181. Siravegna G, Mussolin B, Buscarino M, Corti G, Cassingena A, Crisafulli G, Ponzetti A, Cremolini C, Amatu A, Lauricella C et al (2015) Clonal evolution and resistance to EGFR blockade in the blood of colorectal cancer patients. Nat Med 21(7):827

182. Newman AM, Lovejoy AF, Klass DM, Kurtz DM, Chabon JJ, Scherer F, Stehr H, Liu CL, Bratman SV, Say C et al (2016) Integrated digital error suppression for improved detection of circulating tumor DNA. Nat Biotechnol. https://doi.org/10.1038/nbt.3520

183. Girotti MR, Gremel G, Lee R, Galvani E, Rothwell D, Viros A, Mandal AK, Lim KH, Saturno G, Furney SJ et al (2016) Application of sequencing, liquid biopsies, and patient-derived xenografts for personalized medicine in melanoma. Cancer Discov 6(3):286-299

184. Lohr JG, Adalsteinsson VA, Cibulskis K, Choudhury AD, Rosenberg M, Cruz-Gordillo P, Francis JM, Zhang CZ, Shalek AK, Satija R et al (2014) Whole-exome sequencing of circulating tumor cells provides a window into metastatic prostate cancer. Nat Biotechnol 32(5):479-484
185. Shao H, Chung J, Balaj L, Charest A, Bigner DD, Carter BS, Hochberg FH, Breakefield XO, Weissleder R, Lee H (2012) Protein typing of circulating microvesicles allows real-time monitoring of glioblastoma therapy. Nat Med 18(12):1835-1840

186. Chen WW, Balaj L, Liau LM, Samuels ML, Kotsopoulos SK, Maguire CA, Loguidice L, Soto H, Garrett M, Zhu LD et al (2013) BEAMing and droplet digital PCR analysis of mutant IDH1 mRNA in glioma patient serum and cerebrospinal fluid extracellular vesicles. Mol Ther Nucleic Acids 2:e109

187. Best MG, Sol N, Kooi I, Tannous J, Westerman BA, Rustenburg F, Schellen P, Verschueren H, Post E, Koster J et al (2015) RNA-Seq of tumor-educated platelets enables blood-based pan-cancer, multiclass, and molecular pathway cancer diagnostics. Cancer Cell 28(5):666-676

188. Pan W, Gu W, Nagpal S, Gephart MH, Quake SR (2015) Brain tumor mutations detected in cerebral spinal fluid. Clin Chem 61(3):514-522

189. Wang Y, Springer S, Zhang M, McMahon KW, Kinde I, Dobbyn L, Ptak J, Brem H, Chaichana K, Gallia GL et al (2015) Detection of tumor-derived DNA in cerebrospinal fluid of patients with primary tumors of the brain and spinal cord. Proc Natl Acad Sci U S A 112(31):9704-9709

190. Shi R, Wang PY, Li XY, Chen JX, Li Y, Zhang XZ, Zhang CG, Jiang T, Li WB, Ding W et al (2015) Exosomal levels of miRNA-21 from cerebrospinal fluids associated with poor prognosis and tumor recurrence of glioma patients. Oncotarget 6(29):26971-26981

191. Touat M, Duran-Pena A, Alentorn A, Lacroix L, Massard C, Idbaih A (2015) Emerging circulating biomarkers in glioblastoma: promises and challenges. Expert Rev Mol Diagn 15(10):13111323

192. Bardelli A, Pantel K (2017) Liquid biopsies, what we do not know (yet). Cancer Cell 31(2):172-179

193. Diaz LA Jr, Williams RT, Wu J, Kinde I, Hecht JR, Berlin J, Allen B, Bozic I, Reiter JG, Nowak MA et al (2012) The molecular evolution of acquired resistance to targeted EGFR blockade in colorectal cancers. Nature 486(7404):537-540

194. De Mattos-Arruda L, Caldas C (2016) Cell-free circulating tumour DNA as a liquid biopsy in breast cancer. Mol Oncol 10(3):464-474

195. Siravegna G, Marsoni S, Siena S, Bardelli A (2017) Integrating liquid biopsies into the management of cancer. Nat Rev Clin Oncol 14(9):531-548

196. Abbosh C, Birkbak NJ, Wilson GA, Jamal-Hanjani M, Constantin T, Salari R, Le Quesne J, Moore DA, Veeriah S, Rosenthal R et al (2017) Phylogenetic ctDNA analysis depicts early-stage lung cancer evolution. Nature 545(7655):446-451

197. Litjens G, Sanchez CI, Timofeeva N, Hermsen M, Nagtegaal I, Kovacs I, Hulsbergen-van de Kaa C, Bult P, van Ginneken B, van der Laak J (2016) Deep learning as a tool for increased accuracy and efficiency of histopathological diagnosis. Sci Rep 6:26286

198. Mobadersany P, Yousefi S, Amgad M, Gutman DA, BarnholtzSloan JS, Velazquez Vega JE, Brat DJ, Cooper LAD (2018) Predicting cancer outcomes from histology and genomics using convolutional networks. Proc Natl Acad Sci U S A 115(13): E2970-E2979

199. Bychkov D, Linder N, Turkki R, Nordling S, Kovanen PE, Verrill C, Walliander M, Lundin M, Haglund C, Lundin J (2018) Deep learning based tissue analysis predicts outcome in colorectal cancer. Sci Rep 8(1):3395

200. Michaut M, Chin SF, Majewski I, Severson TM, Bismeijer T, de Koning L, Peeters JK, Schouten PC, Rueda OM, Bosma AJ et al (2016) Integration of genomic, transcriptomic and proteomic data identifies two biologically distinct subtypes of invasive lobular breast cancer. Sci Rep 6:18517

201. Gilmore SJ (2018) Automated decision support in melanocytic lesion management. PLoS One 13(9):e0203459 
202. Yu KH, Zhang C, Berry GJ, Altman RB, Re C, Rubin DL, Snyder M (2016) Predicting non-small cell lung cancer prognosis by fully automated microscopic pathology image features. Nat Commun 7:12474

203. Djuric U, Zadeh G, Aldape K, Diamandis P (2017) Precision histology: how deep learning is poised to revitalize histomorphology for personalized cancer care. NPJ Precis Oncol 1(1):22
204. Horning SJ (2017) A new cancer ecosystem. Science 355(6330): 1103

Publisher's note Springer Nature remains neutral with regard to jurisdictional claims in published maps and institutional affiliations. 